\title{
Commercial spices and industrial ingredients: evaluation of antioxidant capacity and flavonoids content for functional foods development
}

\author{
Condimentos comerciais e ingredientes industriais: avaliação da capacidade antioxidante e do conteúdo de \\ flavonóides para o desenvolvimento de alimentos funcionais
}



\begin{abstract}
The aim of this work was to evaluate spices and industrial ingredients for the development of functional foods with high phenolic contents and antioxidant capacity. Basil, bay, chives, onion, oregano, parsley, rosemary, turmeric and powdered industrial ingredients $(\beta$-carotene, green tea extract, lutein, lycopene and olive extract) had their in vitro antioxidant capacity evaluated by means of the Folin-Ciocalteu reducing capacity and DPPH scavenging ability. Flavonoids identification and quantification were performed by High Performance Liquid Chromatography (HPLC). The results showed that spices presented a large variation in flavonoids content and in vitro antioxidant capacity, according to kind, brand and batches. Oregano had the highest antioxidant capacity and parsley had the highest flavonoid content. The industrial ingredient with the highest antioxidant capacity was green tea extract, which presented a high content of epigalocatechin gallate. Olive extract also showed a high antioxidant activity and it was a good source of chlorogenic acid. This study suggests that oregano, parsley, olive and green tea extract have an excellent potential for the development of functional foods rich in flavonoids as antioxidant, as long as the variability between batches/brands is controlled.

Keywords: antioxidants; industrial ingredients; food development; functionality; phenolic compounds; spices.
\end{abstract}

\section{Resumo}

O objetivo deste trabalho foi avaliar condimentos e ingredientes industriais para o desenvolvimento de alimentos funcionais com alto conteúdo de compostos fenólicos e capacidade antioxidante. Manjericão, louro, cebolinha, cebola, orégano, salsa, alecrim, cúrcuma e ingredientes industriais em pó ( $\beta$-caroteno, extrato de chá verde, luteína, licopeno e extrato de azeitona) tiveram sua capacidade antioxidante in vitro avaliada pelos métodos da capacidade redutora do Folin-Ciocalteu e capacidade sequestrante do DPPH. A identificação e a quantificação dos flavonoides foram realizadas por cromatografia líquida de alta eficiência (CLAE). Os resultados demonstram que os condimentos apresentaram uma ampla variação no conteúdo de flavonoides e capacidade antioxidante in vitro, conforme o tipo, marca e lotes. Orégano apresentou a maior capacidade antioxidante e salsa, o maior conteúdo de flavonoides. O ingrediente industrial com a maior capacidade antioxidante foi o extrato de chá verde, o qual apresentou um elevado teor de epigalocatequina galato. O extrato de azeitona também demonstrou uma alta capacidade antioxidante e mostrou-se boa fonte de ácido clorogênico. Este estudo sugere que orégano, salsa, extrato de azeitona e extrato de chá verde têm um excelente potencial para o desenvolvimento de alimentos funcionais ricos em flavonoides como antioxidantes, desde que a variabilidade entre lotes/marcas possa ser controlada.

Palavras-chave: antioxidantes; ingredientes industriais; desenvolvimento de alimentos; funcionalidade; compostos fenólicos; condimentos.

\section{Introduction}

Due to the incomplete efficiency of our endogenous protection system, the influence of environmental factors such as smoking, pollution, UV radiation, diet, and some physiopathological processes (aging, obesity, inflammation and ischemia), it is well established that bioactive compounds from our diet can help supply this deficiency and promote protection, prevention or reduction of the effects caused by oxidative stress (HUANG; OU; PRIOR, 2005; PIETTA, 2000).

Traditionally, industrial foods are developed to supply the requirements of consumers in relation to taste, appearance, market value, and practicality, to prepare/consume. The development of products to provide beneficial effects on health is a new trend and reflects the increasing acceptance of the role of diet in reducing the risk of chronic diseases (GUTHMAN, 2003; GRUNERT, 2002; STEPHEN, 1998).

In recent years, there has been an increasing interest of the food industry in incorporating ingredients with health beneficial properties (HERRERO; CIFUENTES; IBAÑEZ, 2006). Among these ingredients, spices are recognized by their flavoring and coloring potential. Many of them are known for being linked to numerous health benefits, such as anti-inflammatory, antimicrobial, antimutagenic, antioxidant and hypolipidemic activities (SU et al., 2007).

Spices may contain phenolic compounds and contribute to the intake of natural antioxidants, which promote the protection

Received 27/10/2009

Accepted 18/1/2010 (004482)

${ }^{1}$ Laboratório de Química, Bioquímica e Biologia Molecular de Alimentos, Departamento de Alimentos e Nutrição Experimental, FCF, Universidade de São Paulo - USP,

Av. Prof. Lineu Prestes, 580, Bloco 14, CEP 05508-900, São Paulo, SP, Brazil, E-mail: genovese@usp.br

${ }^{*}$ Corresponding author 
of important cellular components such as DNA, proteins and lipid membranes against the action of reactive oxygen species (SU et al., 2007). Phenolic compounds have redox properties, which may be the result of several mechanisms: free radicals scavenging ability, chelating activity for transition metals and/or reduction of singlet oxygen. Moreover, these compounds are also known for their role in avoiding lipid peroxidation and inhibiting several types of oxidative enzymes, especially rosemary and oregano (SHAN et al., 2005).

Crude extracts of fruits, herbs, vegetables, cereals and other plant materials rich in phenolics have attracted the interest of the food industry, because of their ability to retard the oxidative degradation of lipids and, thereby, improve the quality and nutritional value of foods (XU, 2009; KÄKHÖNEN et al., 1999). Recently, the synergistic effects of phytochemicals in the regulation of gene expression and its potential use in "functional foods" have been reported. The results of these studies not only encourage consumers to modify their eating habits, but also stimulate the development of ingredients containing such compounds, with beneficial effects on health (HERRERO; CIFUENTES; IBAÑEZ, 2006).

As industrial ingredients, the extracts are available in water soluble form. Some carotenoids, such as lutein, lycopene and $\beta$-carotene were used for the development of functional ingredients. Bioactive compounds present in green tea and olive also have been used in the development of extracts containing functional properties (PSZCZOLA, 2002).

Therefore, the incorporation of purified extracts of bioactive compounds in many foods may represent an interesting alternative to increase consumption of these substances and allow the population to benefit from the positive effects attributed to them (BITLER et al., 2007).

Various vegetables consumed in Brazil were analyzed in relation to their content of flavonoids, and an average daily intake of $82 \mathrm{mg}$ was estimated. However, 70\% were derived from oranges, indicating low consumption and few sources of these compounds in our diet (ARABBI; GENOVESE; LAJOLO, 2004). In this way, this work aimed to identify the main sources of bioactive compounds and their antioxidant capacity, among the spices usually consumed by the Brazilian population, as well as new industrial ingredients with high potential of use in functional foods.

\section{Materials and methods}

\subsection{Materials}

Dehydrated spices and industrial ingredients were obtained from producers in the State of Sao Paulo, Brazil. The spices were as follows: basil (Ocimum basilicum L.), bay (Laurus nobilis L.), chives (Allium fistulosum L.), onion (Allium cepa L.), oregano (Origanum vulgare L.), parsley (Petroselinum crispum L.), rosemary (Rosmarinus officinalis L.) and turmeric (Curcuma longa L.). Three different batches and three different brands were analyzed. Powdered industrial ingredients included: $\beta$-carotene, green tea extract, lutein, lycopene and olive extract. Only one batch and one brand from each ingredient were analyzed. When necessary, spices were thoroughly homogenized through powdering in liquid nitrogen. All samples were stored at $-20^{\circ} \mathrm{C}$ until analysis. All chemicals and solvents were reagent or HPLC grade.

\subsection{Methods}

\section{Flavonoids content}

Extraction was performed according to the method of Arabbi, Genovese and Lajolo (2004) with some modifications. Samples of homogenized spices and industrial ingredients $(0.5 \mathrm{~g})$ were extracted in a solvent mixture $(20 \mathrm{~mL})$ comprising methanol/water $(70: 30 \mathrm{v} / \mathrm{v})$ at $10000 \times \mathrm{g}$ for 1 minute (Brinkmann homogenizer, Polytron; Kinematica GmbH) while cooled in ice. The homogenate was filtered through filter paper (Whatman № 1) and evaporated under vacuum at $40{ }^{\circ} \mathrm{C}$ to $\sim 2 \mathrm{~mL}$ in a rotator evaporator and made up with water to $5 \mathrm{~mL}$. The extract was added to a $1 \mathrm{~g}$ polyamide SC6 column (Macherey-Nagel Gmbh and Co, Düren, Germany) preconditioned with methanol $(20 \mathrm{~mL})$ and water $(60 \mathrm{~mL})$. The column was washed with water $(20 \mathrm{~mL})$ and further eluted with methanol $(40 \mathrm{~mL})$ - to elute the neutral flavonols; and with methanol/ammonia $(99.5: 0.5 \mathrm{v} / \mathrm{v})$ - to elute the acidic flavonols. These fractions were evaporated to dryness under pressure at $40^{\circ} \mathrm{C}$, redissolved in HPLC grade methanol $(1 \mathrm{~mL})$, filtered through $0.22 \mu \mathrm{m}$ PTFE (polytetrafluoroethylene) filters (Millipore Ltd., Bedford, MA), and analyzed by HPLC.

\section{HPLC Analysis}

Identification and quantification of flavonoids were achieved using analytical reversed-phase HPLC in a Hewlett-Packard 1100 system with autosampler and quaternary pump coupled to a diode array detector. The column used was $250 \times 4.6 \mathrm{~mm}$, i.d., $5 \mu \mathrm{m}$, Prodigy ODS3 reversed phase silica (Phenomenex Ltd., Torrance, CA); and elution solvents were: A, water: tetrahydrofuran:trifluoroacetic acid $(98: 2: 0.1 \mathrm{v} / \mathrm{v})$ and $\mathrm{B}$, acetonitrile. Solvent gradient was the same used by Pinto, Lajolo and Genovese (2008), in the proportion of $17 \%$ B for 2 minutes, increasing to $25 \%$ B after 5 minutes, to $35 \%$ B after a further 8 minutes and to $50 \%$ B after 5 minutes. Samples were injected in duplicate. Calibration was performed by injecting the standards three times at five different concentrations $\left(R^{2}>\right.$ 0.999). Results were expressed as $\mathrm{mg}$ aglycon. $100 \mathrm{~g}^{-1}$ sample (f.w.).

\section{Folin-Ciocalteu reducing ability}

This method was used for the estimation of the total phenolic contents of the spices. A measure of antioxidant capacity was used for the industrial ingredients. The determination was performed according to Singleton, Orthofer and LamuelaRaventos (1999) with some modifications (GENOVESE et al., 2003). The dehydrated spices were extracted in a solvent mixture comprising methanol/water $(70: 30 \mathrm{v} / \mathrm{v})$. The industrial ingredient extracts were obtained by dispersion of powdered ingredients in five solvents (water, methanol, methanol/water $(70: 30 \mathrm{v} / \mathrm{v})$, ethyl acetate and hexane). The homogenate was filtered under reduced pressure through filter paper (Whatman 
No 1). A $0.25 \mathrm{~mL}$ aliquot was mixed with $0.25 \mathrm{~mL}$ of the FolinCiocalteu reagent and $2 \mathrm{~mL}$ of distillated water. After 3 minutes at room temperature, $0.25 \mathrm{~mL}$ of a saturated sodium carbonate $\left(\mathrm{Na}_{2} \mathrm{CO}_{3}\right)$ solution was added and the mixture was placed at $37^{\circ} \mathrm{C}$ in water bath for 30 minutes. The absorbance was measured at $750 \mathrm{~nm}$ using an Ultrospec $2000 \mathrm{UV} /$ Visible model spectrophotometer (Amersham Biosciences, Cambridge, UK). The results were expressed as $\mathrm{g}$ of catechin. $100 \mathrm{~g}^{-1}$ samples (f.w.).

\section{DPPH Radical scavenging activity}

The extracts obtained above were used to assess the antioxidant capacity through DPPH (2, 2-diphenyl-1picrylhydrazyl) radical-scavenging method, according to BrandWilliams, Cuvelier and Berset (1995) with some modifications (DUARTE-ALMEIDA et al., 2006). A $50 \mu \mathrm{L}$ aliquot of the extract previously diluted and $250 \mu \mathrm{L}$ of DPPH $(0.5 \mathrm{~mm})$ were shaken, and after 25 minutes the absorbance was measured at $517 \mathrm{~nm}$ using a Microplate Spectrophotometer (Benchmark Plus, Biorad, Hercules, CA). The standard curve consisted of a methanolic solution of Trolox (6-hydroxy-2,5,7,8-tetramethylchroman-2carboxylic acid) at different concentrations (20, 30, 40, 50, 60, 70 and $80 \mu \mathrm{m}$ ). The antioxidant capacity was expressed as mmols Trolox equivalents. $100 \mathrm{~g}^{-1}$ sample (f.w.).

\section{Statistical analysis}

All analyses were run in triplicate and were expressed as mean \pm standard deviation (SD). Statistical analysis was done by using the Statistic software package version 5.0 (StatSoft, Inc., Tulsa, OK). Differences between means were first analyzed by ANOVA test and then followed by post hoc Newman-Keuls test $(\mathrm{p} \leq 0.05)$.

\section{Results and discussion}

\subsection{Spices}

Spices and other seasonings were analyzed in relation to total phenolic contents (Folin-Ciocalteu reducing capacity) (Table 1).

There was a very wide variation in the total phenolic contents between the types and brands of dehydrated spices. Oregano

Table 1. Total phenolic contents (Folin-Ciocalteu reducing capacity) expressed as g catechin equivalents. $100 \mathrm{~g}^{-1}$ (f.w.) of dehydrated spices (A, B and C brands).

\begin{tabular}{lccc}
\hline \multirow{2}{*}{ Spices } & \multicolumn{3}{c}{ Total phenolic contents } \\
\cline { 2 - 4 } & A-Brand & B-Brand & C-Brand \\
\hline Basil & $12.8 \pm 0.2^{\mathrm{c}, \mathrm{A}}$ & $5.25 \pm 0.02^{\mathrm{d}, \mathrm{B}}$ & $2.5 \pm 0.2^{\mathrm{d}, \mathrm{C}}$ \\
Bay & $5.1 \pm 0.3^{\mathrm{d}, \mathrm{B}}$ & $6.18 \pm 0.04^{\mathrm{b}, \mathrm{A}}$ & $2.58 \pm 0.03^{\mathrm{d}, \mathrm{C}}$ \\
Chives & $2.4 \pm 0.1^{\mathrm{e}, \mathrm{f}, \mathrm{B}}$ & $0.722 \pm 0.001^{\mathrm{g}, \mathrm{C}}$ & $3.05 \pm 0.03^{\mathrm{c}, \mathrm{A}}$ \\
Onion & $0.145 \pm 0.002^{\mathrm{g}, \mathrm{C}}$ & $0.293 \pm 0.004^{\mathrm{h}, \mathrm{B}}$ & $0.325 \pm 0.004^{\mathrm{f}, \mathrm{A}}$ \\
Oregano & $30.8 \pm 0.2^{\mathrm{a}, \mathrm{A}}$ & $9.31 \pm 0.14^{\mathrm{a}, \mathrm{B}}$ & $6.6 \pm 0.1^{\mathrm{a}, \mathrm{C}}$ \\
Parsley & $1.05 \pm 0.01^{\mathrm{f}, \mathrm{C}}$ & $1.248 \pm 0.004^{\mathrm{f}, \mathrm{B}}$ & $1.40 \pm 0.03^{\mathrm{e}, \mathrm{A}}$ \\
Rosemary & $22.0 \pm 0.2^{\mathrm{b}, \mathrm{A}}$ & $5.93 \pm 0.03^{\mathrm{c}, \mathrm{B}}$ & $5.4 \pm 0.1^{\mathrm{b}, \mathrm{B}}$ \\
Turmeric & $3.21 \pm 0.04^{\mathrm{e}, \mathrm{A}}$ & $1.4 \pm 0.1^{\mathrm{e}, \mathrm{C}}$ & $2.9 \pm 0.1^{\mathrm{c}, \mathrm{B}}$ \\
\hline All values were the average of three measurements and were expressed as mean \pm SD \\
(triplicate). Means in the same column (letters) with common letters are not significantly \\
different (p $\leq 0.05$ ). Means in the same line (capital letters) with common letters are not \\
significantly different (p $\leq 0.05$ ).
\end{tabular}

was the spice with the greatest antioxidant activity, followed by rosemary, bay and basil. Onion had the lowest activity. The A-brand presented the highest total phenolic contents, whereas the C-brand exhibited the lowest one. Among the batches, total phenolic contents of the spices did not show a significant variation among the brands, ranging from 33 (parsley) to $36 \%$ (oregano) (Table 1). These differences may complicate the use of spices for the development of functional foods.

Shan et al. (2005) analyzed 26 different spices in relation to total phenolic contents. The results of their study are similar to those obtained in the present one, confirming the high total phenolic content of oregano.

DPPH scavenging ability also varied significantly among the spices and the different brands (Table 2).

Among the tested spices, oregano had the highest anti-radical capacity. Shan et al. (2005) also reported the expressive antioxidant potential of oregano between 26 common spices analyzed in their study. DPPH scavenging ability of the spices did not show a significant variation between batches, ranging from 0.3 to $8.3 \%$. The A-brand presented the highest radical scavenging activity, whereas the $\mathrm{C}$-brand exhibited the lowest values for the DPPH assay. Anti-radical capacity also presented a very wide variation between the brands (from 168 to $782 \%)$. The lowest variation was observed in chives and the highest was found in onion.

Some researchers agree that rosemary has the highest antioxidant capacity among spices. However, other studies suggest that oregano and bay may be more potent. These differences may be related to the genotype of species, environmental factors (soil, temperature, and moisture), time of sample collection, analytical methods, and others (ÜNVER et al., 2009; SHAN et al., 2005; DRAGLAND et al., 2003). The antioxidant capacity of extracts of oregano was determined and compared to other herbs, fruits and vegetables. The results indicated that oregano had 3-20 times higher antioxidant activity than the other spices analyzed by means of ORAC assay and total phenolic contents (ZHENG; WANG, 2001). In addition, oregano had 42 times more antioxidant activity than apples, 30 times more than potatoes, 12 times more than oranges and 4 times more than blueberries (AMERICAN..., 2002).

Table 2. DPPH scavenging ability, expressed as mmoles Trolox equivalents. $100 \mathrm{~g}^{-1}$ (f.w.) from dehydrated spices (A, B and C brands).

\begin{tabular}{lccc}
\hline \multirow{2}{*}{ Spices } & \multicolumn{3}{c}{ Radical scavenging ability } \\
\cline { 2 - 4 } & A-Brand & B-Brand & C-Brand \\
\hline Basil & $26.5 \pm 0.3^{\mathrm{d}, \mathrm{B}}$ & $37 \pm 3^{\mathrm{b}, \mathrm{A}}$ & $6.2 \pm 0.2^{\mathrm{d}, \mathrm{C}}$ \\
Bay & $64.8 \pm 0.2^{\mathrm{c}, \mathrm{A}}$ & $34 \pm 1^{\mathrm{c}, \mathrm{B}}$ & $15.7 \pm 0.1^{\mathrm{b}, \mathrm{C}}$ \\
Chives & $3.22 \pm 0.03^{\mathrm{f}, \mathrm{A}}$ & $1.2 \pm 0.1^{\mathrm{f}, \mathrm{B}}$ & $1.3 \pm 0.01^{\mathrm{g}, \mathrm{B}}$ \\
Onion & $0.17 \pm 0.01^{\mathrm{g}, \mathrm{C}}$ & $0.55 \pm 0.01^{\mathrm{f}, \mathrm{B}}$ & $1.5 \pm 0.1^{\mathrm{g}, \mathrm{A}}$ \\
Oregano & $130 \pm 2^{\mathrm{a}, \mathrm{A}}$ & $58 \pm 1^{\mathrm{a}, \mathrm{B}}$ & $16.4 \pm 0.2^{\mathrm{a}, \mathrm{C}}$ \\
Parsley & $1.00 \pm 0.03^{\mathrm{g}, \mathrm{C}}$ & $1.9 \pm 0.1^{\mathrm{f}, \mathrm{B}}$ & $3.7 \pm 0.1^{\mathrm{f}, \mathrm{A}}$ \\
Rosemary & $101 \pm 1^{\mathrm{b}, \mathrm{A}}$ & $36 \pm 1^{\mathrm{b}, \mathrm{B}}$ & $13.6 \pm 0.2^{\mathrm{c}, \mathrm{C}}$ \\
Turmeric & $16.1 \pm 0.3^{\mathrm{e}, \mathrm{A}}$ & $9 \pm 0.2^{\mathrm{d}, \mathrm{B}}$ & $4.4 \pm 0.2^{\mathrm{e}, \mathrm{C}}$ \\
\hline
\end{tabular}

All values were the average of three measurements and were expressed as mean \pm SD (triplicate). Means in the same column (letters) with common letters are not significantly different $(p \leq 0.05)$. Means in the same line (capital letters) with common letters are not significantly different $(\mathrm{p} \leq 0.05)$. 
Although oregano presented the highest antioxidant activity and total phenolic content, its use as an ingredient in functional foods is limited. This limitation is linked to the fact that this condiment is a genetically heterogeneous species, due to cross-pollination, which may cause a wide variation in the content of bioactive compounds and antioxidant capacity (CHUN et al., 2005).

A high positive correlation was found between total phenolic content and $\mathrm{DPPH}$, mainly for brands $\mathrm{A}$ and $\mathrm{B}$ $(\mathrm{r}=0.99)$. If all data were analyzed together, a high positive correlation would also be found between total phenolic content and $\mathrm{DPPH}$, for the spices of the three brands $(\mathrm{r}=0.92)$.

Shan et al. (2005) analyzed 26 spices in relation to the total phenolic contents and DPPH scavenging ability, with a highly significant linear correlation between both $(r=0.9613)$. In this way, such high correlation coefficient indicates that phenolic compounds are responsible for the anti-radical capacity of spices extracts.

\section{Flavonoids content and profile}

Flavonoids are usually present in glycosylated forms in plants. In our study, the compounds were analyzed in the form they are present in the spices, but the levels were expressed as the equivalent aglycon form. Flavonoids content varied significantly between the types and brands of spices (Tables 3, 4 and 5).

Quercetin, apigenin and their glycosides were the most common compounds among the samples. The highest levels were detected in bay, rosemary and parsley. No flavonoids were detected in turmeric, which is known for being rich in polyphenol curcumin; and high amounts of hydroxycinnamic acids were present in rosemary, basil and oregano.

In relation to spices from B-brand, luteolin, apigenin and their glycosides were the most common compounds among the spices, in addition to the hydroxycinnamic acids. Bay and parsley showed high flavonoid content.

In relation to spices from C-brand, hydroxycinnamic acid and apigenin glycosides were the most common compounds found. Significant amounts of flavonoids were detected in rosemary, bay and parsley.

Turmeric is an important source of a natural antioxidant curcumin, also used as a food coloring agent. This compound has been extensively investigated for the ability to scavenge free radicals and inhibit lipid peroxidation (BIANCHI; ANTUNES, 1999). Turmeric and its components have been also associated with the induction of GSH synthesis in in vitro models (DICKINSON et al., 2003).

Kaempferol glycosides were also detected in various samples, but in low concentrations (less than $1 \mathrm{mg} .100 \mathrm{~g}^{-1}$, except in bay). A study that evaluated the main compounds present in oregano indicated that this spice is a good source of kaempferol (MOLLER; CATHARINO; EBERLIN, 2007), but this flavonoid was not detected in this work. The oregano herb is commonly used in the Mediterranean diet. It has a wide composition of different types of flavonoids, including flavones (apigenin and luteolin), and flavonols (myricetin and quercetin) (SUHAJ, 2006). Similar to our results, Kaefer and Milner (2008) and Skerget, Kotnik and Hadolin (2005) did not find kaempferol in oregano, but they found quercetin, apigenin and myricetin, instead.

Table 3. Flavonoids and hydroxycinnamic contents of spices from A-brand (mg.100 g-1 f.w.).

\begin{tabular}{|c|c|c|c|c|c|c|}
\hline Spices & Apigenin & Luteolin & Kaempferol & Quercetin & Total & $\begin{array}{l}\text { Hydroxycinnamic } \\
\text { acids }\end{array}$ \\
\hline Basil & nd & nd & nd & $86.5 \pm 0.3^{b}$ & $86.5 \pm 0.3^{\mathrm{d}}$ & $231 \pm 1^{c}$ \\
\hline Bay & $16.1 \pm 0.1^{\mathrm{d}}$ & nd & $9.75 \pm 0.01^{\mathrm{b}}$ & $250.0 \pm 0.1^{\mathrm{a}}$ & $275.8 \pm 0.2^{\mathrm{b}}$ & nd \\
\hline Chives & $6.89 \pm 0.01^{\mathrm{e}}$ & nd & $13.33 \pm 0.03^{\mathrm{a}}$ & $32.2 \pm 0.1^{\mathrm{d}}$ & $52.4 \pm 0.2^{\mathrm{e}}$ & $14.86 \pm 0.01^{\mathrm{d}}$ \\
\hline Onion & nd & nd & nd & $51.92 \pm 0.01^{\mathrm{c}}$ & $51.92 \pm 0.01^{\mathrm{e}}$ & nd \\
\hline Oregano & $43 \pm 1^{c}$ & $45 \pm 1^{\mathrm{a}}$ & nd & nd & $88 \pm 2^{\mathrm{d}}$ & $360 \pm 5^{\mathrm{a}}$ \\
\hline Parsley & $560 \pm 3^{\mathrm{a}}$ & $34 \pm 1^{\mathrm{b}}$ & nd & nd & $594 \pm 4^{\mathrm{a}}$ & nd \\
\hline Rosemary & $231 \pm 3^{b}$ & $6.74 \pm 0.01^{\mathrm{c}}$ & nd & nd & $238 \pm 3^{c}$ & $305 \pm 2^{\mathrm{b}}$ \\
\hline Turmeric & nd & nd & nd & nd & - & nd \\
\hline
\end{tabular}

nd not detected. All values were the average of three measurements and expressed as mean \pm SD (triplicate).Means in the same column with common letters are not significantly different $(\mathrm{p} \leq 0.05)$

Table 4. Flavonoids and hydroxycinnamic contents of spices from B-brand (mg.100 g-1 f.w.).

\begin{tabular}{|c|c|c|c|c|c|c|}
\hline Spices & Apigenin & Luteolin & Kaempferol & Quercetin & Total & $\begin{array}{c}\text { Hydroxycinnamic } \\
\text { acids }\end{array}$ \\
\hline Basil & nd & nd & nd & $41 \pm 2^{b}$ & $41 \pm 2^{\mathrm{e}}$ & $190 \pm 7^{c}$ \\
\hline Bay & $13.3 \pm 0.4^{\mathrm{d}}$ & nd & $0.172 \pm 0.002^{\mathrm{b}}$ & $71 \pm 6^{\mathrm{a}}$ & $84 \pm 6^{c}$ & nd \\
\hline Chives & $12 \pm 1^{\mathrm{d}}$ & nd & $8 \pm 1^{\mathrm{a}}$ & $5.88 \pm 0.02^{\mathrm{d}}$ & $26 \pm 2^{\mathrm{f}}$ & $21 \pm 2^{\mathrm{d}}$ \\
\hline Onion & nd & nd & nd & $9.3 \pm 0.1^{c}$ & $9.3 \pm 0.1^{g}$ & nd \\
\hline Oregano & $32.1 \pm 0.3^{c}$ & $37 \pm 1^{\mathrm{b}}$ & nd & nd & $69 \pm 1^{\mathrm{d}}$ & $300 \pm 11^{\mathrm{a}}$ \\
\hline Parsley & $708 \pm 32^{\mathrm{a}}$ & $64 \pm 6^{a}$ & nd & nd & $772 \pm 38^{\mathrm{a}}$ & nd \\
\hline Rosemary & $183 \pm 10^{\mathrm{b}}$ & $30 \pm 1^{\mathrm{b}}$ & nd & nd & $213 \pm 11^{\mathrm{b}}$ & $218 \pm 17^{b}$ \\
\hline Turmeric & nd & nd & nd & nd & - & nd \\
\hline
\end{tabular}

nd not detected. All values were the average of three measurements and expressed as mean \pm SD (triplicate). Means in the same column with common letters are not significantly different $(p \leq 0.05)$. 
Table 5. Flavonoids and hydroxycinnamic contents of spices from C-brand (mg.100 g-1 f.w.).

\begin{tabular}{|c|c|c|c|c|c|c|}
\hline Spices & Apigenin & Luteolin & Kaempferol & Quercetin & Total & $\begin{array}{l}\text { Hydroxycinnamic } \\
\text { acids }\end{array}$ \\
\hline Bay & $14.9 \pm 0.2^{\mathrm{c}}$ & nd & $11.13 \pm 0.02^{\mathrm{a}}$ & $122.9 \pm 0.1^{\mathrm{a}}$ & $148.9 \pm 0.3 b$ & nd \\
\hline Onion & nd & nd & nd & $2.8 \pm 0.2^{c}$ & $2.8 \pm 0.2^{\mathrm{f}}$ & nd \\
\hline Oregano & $2.7 \pm 0.1^{\mathrm{d}}$ & $5.91 \pm 0.01^{c}$ & nd & nd & $8.6 \pm 0.1^{\mathrm{e}}$ & $32.0 \pm 0.2^{c}$ \\
\hline Turmeric & nd & nd & nd & nd & - & nd \\
\hline
\end{tabular}

nd not detected. All values were the average of three measurements and expressed as mean \pm SD (triplicate). Means in the same column with common letters are not significantly different $(\mathrm{p} \leq 0.05)$.

Crozier et al. (1997) identified only quercetin glycosides in onion samples. Similar results were found in our samples of the three brands. Arabbi, Genovese and Lajolo (2004) detected only quercetin glycosides in Brazilian onions.

In the study of Justesen and Knuthsen (2001), flavonoids content from parsley, basil, oregano and rosemary were analyzed. The highest levels were observed in parsley, with a large concentration of apigenin glycosides. Lower amounts of quercetin and luteolin glycosides were also detected. Luteolin was identified in rosemary, and apigenin was detected in oregano. However, no flavonoids were found in basil.

Hydroxycinnamic acids are antioxidant polyphenols common in the human diet (MATEOS; GOYA; BRAVO, 2006). Some researchers affirm that chlorogenic acid is the most common phenolic compound in food and its main sources are fruits, coffee, vegetables, cereals and spices (GONTHIER et al., 2003; CLIFFORD, 1999). In this work, spices were screened for the presence of hydroxycinnamic acids, but these polyphenols were detected only in basil, chives, oregano and rosemary. However, chlorogenic acid was present in low amounts in these samples. Low levels of other hydroxycinnamic acids were detected in spices, such as $p$-coumaric acid and ferulic acid.

Phenolic compounds, such as flavonoids, are secondary metabolites that play important roles in the biochemistry and physiology of plants. In nature, plants produce secondary metabolites as a defense mechanism against attacks by pathogens. The profiles and concentrations of phenolics may also be changed in response to environmental factors (temperature, light, or drought) and are dependent on geographical and seasonal variations. Plant materials, such as spices, are a valuable source of a wide range of secondary metabolites. Recently, modern technologies have lead to the production of plants rich in these compounds. A high accumulation of phenolic compounds, for example, is important due to their use in human nutrition. They can be applied for the production of food additives used in functional food (RAO; RAVISHANKAR, 2002).

\subsection{Industrial ingredients}

Recently, studies showed that bioactive compounds present in foods are associated to beneficial effects on health. In this way, some new food ingredients, rich in bioactive compounds from fruits and vegetables, have been developed for industrial use (SUHAJ, 2006). Lycopene and other carotenoids, such as lutein and $\beta$-carotene, have been used in the development of functional ingredients (PSZCZOLA, 2002).

Green tea extract is rich in polyphenols, which may have an important role as antioxidants (PSZCZOLA, 2002). As an industrial ingredient, it is a water soluble concentrate of epigallocatechin gallate (EGCG). This compound prevented the growth of tumors in liver and intestine in rats (MATSUBARA; RODRIGUEZ-AMAYA, 2006).

Many studies indicated that the consumption of the Mediterranean diet, particularly fish, fresh vegetables, olives and olive oil, may help decrease the risk of developing certain diseases (ATHYROS et al., 2009; MARTÍNEZ-GONZÁLEZ et al., 2008; ESTRUCH et al., 2006; KNOOPS et al., 2004). As a result, it was recently developed an ingredient derived from the aqueous fraction of the olive, which was reported as having high antioxidant and anti-inflammatory activity (BITLER et al., 2007).

In this work, industrial ingredients were analyzed in relation to the antioxidant capacity by two different methods: Folin-Ciocalteu reducing capacity and DPPH scavenging ability. Five solvents were tested to solubilize these ingredients: water, methanol, methanol/water $(70: 30 \mathrm{v} / \mathrm{v})$, ethyl acetate and hexane. However, a poor solubilization or dispersion of the ingredients was observed when using ethyl acetate and hexane. Beta-carotene, olive extract, lycopene and lutein are presented commercially as water soluble formulations. However, in the presence of water, they formed turve dispersions (emulsions), avoiding their antioxidant capacity determination. Thereby, extracts obtained by the dispersion of ingredients in methanol and $70 \%$ aqueous methanol were analyzed. All ingredients showed higher antioxidant capacity when prepared using methanol/water $(70: 30 \mathrm{v} / \mathrm{v})$, except $\beta$-carotene, compared to methanol. The antioxidant capacity of industrial ingredients extracts is shown in Figures 1 and 2.

The ingredient had different antioxidant capacities according to the method applied. Some ingredients, like olive extract, lycopene and lutein, showed a high Folin-Ciocalteu reducing capacity when solubilized in $70 \%$ aqueous methanol. In relation to green tea extract, antioxidant activity of extracts obtained by different solvents was similar. Beta-carotene demonstrated better results when dispersed in methanol.

In relation to DPPH scavenging ability, all ingredients demonstrated higher antioxidant capacity when dispersed in $70 \%$ aqueous methanol, except, again, for $\beta$-carotene. 


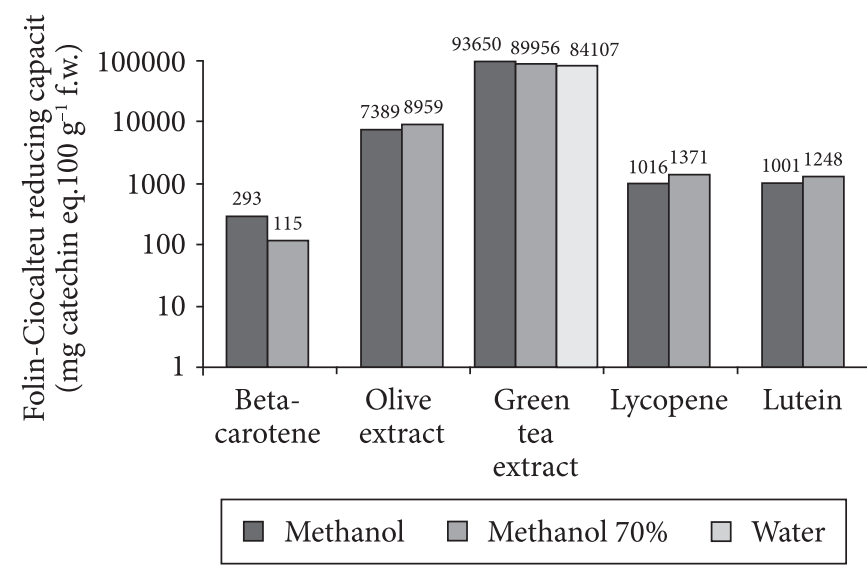

Figure 1. Folin-Ciocalteu reducing capacity of industrial ingredients dispersed in different solvents, expressed as $\mathrm{mg}$ catechin equivalents per $100 \mathrm{~g}$ (f.w.).

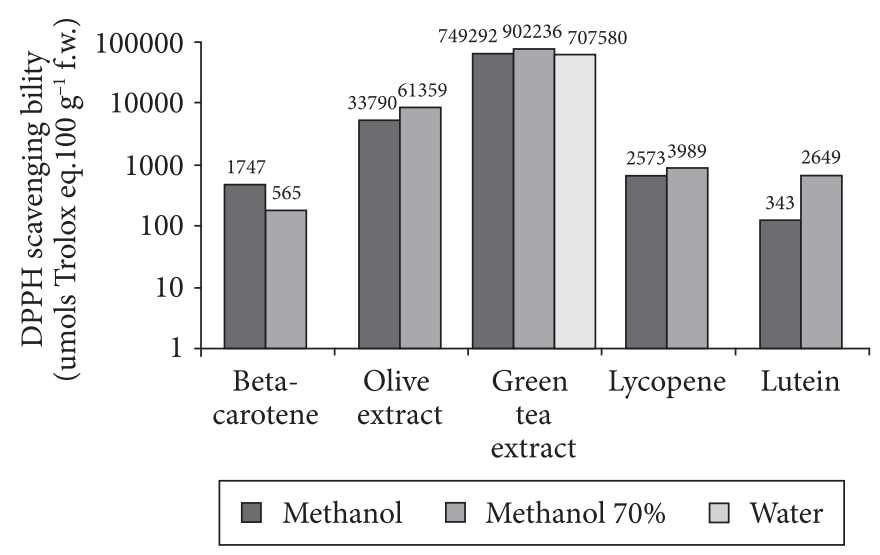

Figure 2. DPPH scavenging ability of industrial ingredients dispersed in different solvents, expressed as $\mu$ mols Trolox equivalents per $100 \mathrm{~g}$ (f.w.).

A selection of an appropriate extraction procedure can increase the antioxidant concentration derived from the ingredient. For polyphenols and other antioxidants, three main extraction methods may be used: extraction using solvents, solid-phase extraction and supercritical extraction. Several extraction techniques have been developed using different solvents, such as petrol ether, acetone, ethanol, methanol, ethyl acetate, and water. Methanol is most commonly employed solvent (SCHWARZ et al., 2001).

Olive extract presented chlorogenic acid in concentrations of $110 \mathrm{mg} .100 \mathrm{~g} \mathrm{~g}^{-1}$ and green tea extract presented a high content of epigallocatechin gallate (EGCG), about $97 \mathrm{~g} .100 \mathrm{~g}^{-1}$.

\section{Conclusions}

According to our results, olive and green tea extracts are the most powerful ingredients for functional foods development. Green tea extract, especially if incorporated in food commonly consumed, may represent an interesting alternative to improve catechin intake. Thus, the Brazilian population can benefit from the health effects attributed to catechins. Carotenoids ingredients, although in theoretically water soluble forms, did not demonstrate expressive ability to increase hydrophilic antioxidant capacity when added to foods.

\section{Acknowledgements}

This research was supported by 'Financiadora de Estudos e Projetos' (FINEP). The authors are grateful to 'Conselho Nacional de Desenvolvimento Científico e Tecnológico' (CNPq) for the grant to Marcela Roquim Alezandro (DTI III mode - Desenvolvimento Tecnológico Industrial 3). Projeto FINEP 01.07.0037.00 (MCT/FINEP/Ação Transv.-Coop. ICTS-Empresas-06/ 2006)/CNPq and 'Sadia' SA. "Ampliação da funcionalidade dos alimentos", from Sep 2007 to Mar 2010. We would also like to thank 'Sadia' S.A. (SP, Brazil) for the collaboration with samples, especially to Ms. Maria Cristina Youn Lui.

\section{References}

AMERICAN CHEMICAL SOCIETY NEWS SERVICE - AChSNS. Researchers call herbs rich source of healthy antioxidants: oregano ranks highest. AChSNS, 2002. Disponível em: <http:// acs.yellowbrix.com>.

ARABBI, P. R.; GENOVESE, M. I.; LAJOLO, F. M. Flavonoids in vegetable foods commonly consumed in Brazil and estimated ingestion by the Brazilian population. Journal of Agriculture and Food Chemistry, v. 52, p. 1124-1131, 2004. PMid:14995109. http:// dx.doi.org/10.1021/jf0499525

ATHYROS, V. G. et al. Effect of a plant stanol ester-containing spread, placebo spread, or Mediterranean diet on estimated cardiovascular risk and lipid, inflammatory and haemostatic factors. Nutrition, Metabolism \& Cardiovascular Diseases, v. 21, n. 3, p. 213-21, 2009. PMid:19939653. http://dx.doi.org/10.1016/j.numecd.2009.08.014

BIANCHI, M. L. P.; ANTUNES, L. M. G. Radicais livres e os principais antioxidantes da dieta. Revista de Nutrição, v. 12, p. 123-130, 1999. http://dx.doi.org/10.1590/S1415-52731999000200001

BITLER, C. M. et al. Olive extract supplement decreases pain and improves daily activities in adults with osteoarthritis and decreases plasma homocysteine in those with rheumatoid arthritis. Nutrition Research, v. 27, p. 470-477, 2007. http://dx.doi.org/10.1016/j. nutres.2007.06.003

BRAND-WILLIAMS, W.; CUVELIER, M. E.; BERSET, C. Use of a free radical method to evaluate antioxidant activity. Lebensmittel Wissenschaft und Technologie - Food Science and Technology, v. 28, p. 25-30, 1995.

CHUN, S. S. et al. Phenolic antioxidants from clonal oregano (Origanum vulgare) with antimicrobial activity against Helicobacter pylori. Process Biochemistry, v. 40, p. 809-816, 2005. http://dx.doi.org/10.1016/j.procbio.2004.02.018

CLIFFORD, M. N. Diet-derived phenols in plasma and tissues and their implications for health. Journal of the Science of Food and Agriculture, v. 79, p. 362-372, 1999. http://dx.doi. org/10.1002/(SICI)1097-0010(19990301)79:3\%3C362::AIDJSFA256\%3E3.0.CO;2-D

CROZIER, A. et al. Quantitative analysis of the flavonoid content of commercial tomatoes, onions, lettuce, and celery. Journal of Agriculture and Food Chemistry, v. 45, p. 590-595, 1997. http://dx.doi.org/10.1021/jf960339y

DICKINSON, D. A. et al. Curcumin alters EpRE and AP-1 binding complexes and elevates glutamate-cysteine ligase gene expression. 
Journal of the Federation of American Societies for Experimental Biology, v. 17, p. 473-475, 2003.

DRAGLAND, S. et al. Several Culinary and Medicinal Herbs Are Important Sources of Dietary Antioxidants. The Journal of Nutrition, v. 133, p. 1286-90, 2003.

DUARTE-ALMEIDA, J. M. et al. Avaliação da atividade antioxidante utilizando sistema $\beta$-caroteno/ácido linoléico e método de sequestro de radicais DPPH ${ }^{\bullet}$. Ciência e Tecnologia de Alimentos, v. 26, p. 446-452, 2006. http://dx.doi.org/10.1590/S010120612006000200031

ESTRUCH, R. et al. Effects of a Mediterranean-style diet on cardiovascular risk factors: a randomized trial. Annals of Internal Medicine, v. 145, p. 1-11, 2006.

GENOVESE, M. I. et al. Avaliação do teor de isoflavonas de "suplementos nutricionais à base de soja". Revista Brasileira de Ciências Farmacêuticas, v. 39, p. 159-167, 2003. http://dx.doi. org/10.1590/S1516-93322003000200006

GONTHIER, M. P. et al. Chlorogenic Acid Bioavailability Largely Depends on Its Metabolism by the Gut Microflora in Rats. The Journal of Nutrition, v. 133, p. 1853-1859, 2003.

GRUNERT, K. G. Current issues in the understanding of consumer food choice. Trends in Food Science \& Technology, v. 13, p. 275-85, 2002. http://dx.doi.org/10.1016/S0924-2244(02)00137-1

GUTHMAN, J. Fast food/organic food: reflexive tastes and the making of 'yuppie chow'. Social \& Cultural Geography, v. 4, p. 45-58, 2003. http://dx.doi.org/10.1080/1464936032000049306

HERRERO, M.; CIFUENTES, A.; IBAÑEZ, E. Sub- and supercritical fluid extraction of functional ingredients from different natural sources: Plants, food-by-products, algae and microalgae: a review. Food Chemistry, v. 98, p. 136-48, 2006. http://dx.doi.org/10.1016/j. foodchem.2005.05.058

HUANG, D.; OU, B.; PRIOR, R. L. The chemistry behind antioxidant capacity assays. Journal of Agriculture and Food Chemistry, v. 53, p. 1841-1856, 2005. PMid:15769103. http://dx.doi.org/10.1021/ jf030723c

JUSTESEN, U.; KNUTHSEN, P. Composition of flavonoids in fresh herbs and calculation of flavonoid intake by use oh herbs in traditional Danish dishes. Food Chemistry, v. 73, p. 245-250, 2001. http://dx.doi.org/10.1016/S0308-8146(01)00114-5

KAEFER, C. M.; MILNER, J. A. The role of herbs and spices in cancer prevention. Journal of Nutritional Biochemistry, v. 19, p. 347-361, 2008. PMid:18499033. PMCid:2771684. http://dx.doi.org/10.1016/j. jnutbio.2007.11.003

KÄHKÖNEN, M. P. et al. Antioxidant activity of plant extracts containing phenolic compounds. Journal of Agriculture and Food Chemistry, v. 47, p. 3954-3962, 1999. http://dx.doi.org/10.1021/ jf9901461

KNOOPS, K. T. et al. Mediterranean diet, lifestyle factors, and 10year mortality in elderly European men and women: the HALE project. The Journal of the American Medical Association, v. 292, p. 1433-1439, 2004. PMid:15383513. http://dx.doi.org/10.1001/ jama.292.12.1433

MARTÍNEZ-GONZÁLEZ, M. A. et al. Adherence to Mediterranean diet and risk of developing diabetes: prospective cohort study. British Medical Journal, v. 336, p. 1348-51, 2008. PMid:18511765. PMCid:2427084. http://dx.doi.org/10.1136/bmj.39561.501007.BE

MATEOS, R.; GOYA, L.; BRAVO, L. Uptake and Metabolism of Hydroxycinnamic Acids (Chlorogenic, Caffeic, and Ferulic Acids) by HepG2 Cells as a Model of the Human Liver. Journal of Agricultural and Food Chemistry, v. 54, p. 8724-8732, 2006. PMid:17090113. http://dx.doi.org/10.1021/jf061664g

MATSUBARA, S.; RODRIGUEZ-AMAYA, D. B. Teores de catequinas e teaflavinas em chás comercializados no Brasil. Ciência e Tecnologia de Alimentos, v. 26, p. 401-407, 2006. http://dx.doi.org/10.1590/ S0101-20612006000200024

MOLLER, J. K. S.; CATHARINO, R. R.; EBERLIN, M. N. Electrospray ionization mass spectrometry fingerprinting of essential oils: Spices from the Labiatae family. Food Chemistry, v. 100, p. 1283-1288, 2007. http://dx.doi.org/10.1016/j.foodchem.2005.10.013

PIETTA, P. G. Flavonoids as antioxidants. Journal of Natural Products, v. 63, p. 1035-1042, 2000. PMid:10924197. http://dx.doi. org/10.1021/np9904509

PINTO, M. S.; LAJOLO, F. M.; GENOVESE, M. I. Bioactive Compounds and Quantification of Total Ellagic Acid in Strawberries (Fragaria $\mathrm{x}$ ananassa Duch.). Food Chemistry, v. 107, p. 1629-1635, 2008.

PSZCZOLA, D. E. Evolving ingredients components offer specific health value. Food Technology, v. 56, p. 50-59, 2002.

RAO, S. R.; RAVISHANKAR, G. A. Plant cell cultures: Chemical factories of secondary metabolites. Biotechnology Advances, v. 20, p. 101-153, 2002. http://dx.doi.org/10.1016/S0734-9750(02)00007-1

SCHWARZ, K. et al. Investigation of plant extracts for the protection of processed foods against lipid oxidation. Comparison of antioxidant assays based on radical scavenging. Lipid oxidation and analysis of the principal antioxidant compounds. European Food Research and Technology, v. 212, p. 319-328, 2001. http://dx.doi.org/10.1007/ s002170000256

SHAN, B. et al. Antioxidant capacity of 26 spice extracts and characterization of their phenolic constituents. Journal of Agriculture and Food Chemistry, v. 53, p. 7749-7759, 2005. PMid:16190627. http://dx.doi.org/10.1021/jf051513y

SINGLETON, V. L.; ORTHOFER, R.; LAMUELA-RAVENTOS, R. M. Analysis of total phenols and other oxidation substrates and antioxidants by means of Folin-Ciocalteu reagente. Methods of Enzymology, v. 299, p. 152-178, 1999. http://dx.doi.org/10.1016/ S0076-6879(99)99017-1

Skerget, A. M.; KOTNiK, A. P.; HADOlin, B. M. Phenols, proanthocyanidins, flavones and flavonols in some plant materials and their antioxidant activities. Food Chemistry, v. 89, p. 191-198, 2005. http://dx.doi.org/10.1016/j.foodchem.2004.02.025

STEPHEN, A. M. Regulatory aspects of functional products. In: MAZZA, G. Functional foods: biochemical \& processing aspects. Lancaster: Technomic, 1998. p. 403-437.

SU, L. et al. Total phenolic contents, chelating capacities, and venging properties of black peppercorn, nutmeg, rosehip, cinnamon and oregano leaf. Food Chemistry, v. 100, p. 990-997, 2007. http:// dx.doi.org/10.1016/j.foodchem.2005.10.058

SUHAJ, M. Spice antioxidants isolation and their antiradical activity: a review. Journal of Food Composition and Analysis, v. 19, p. 531-537, 2006. http://dx.doi.org/10.1016/j.jfca.2004.11.005

ÜNVER, A. et al. Phenolic content and antioxidant activity of some spices. World Applied Sciences Journal, v. 6, p. 373-7, 2009.

XU, Z. Antioxidants in grains, vegetables and fruits. Food Science \& Technology Bulletin: Functional Foods, v. 5, p. 61-70, 2009. http:// dx.doi.org/10.1616/1476-2137.15600

ZHENG, W.; WANG, S. Y. Antioxidant activity and phenolic compounds in selected herbs. Journal of Agriculture and Food Chemistry, v. 49, n. 11, p. 5165-70, 2001. PMid:11714298. http:// dx.doi.org/10.1021/jf010697n 